\title{
Analysis of the Traditional Marriage of the Dayak Kadorih Tribe in the Perspective of Law Number 1 of 1974 Concerning Marriage
}

\author{
David $^{1}$, Zudan Arief Fakrulloh ${ }^{2}$ \\ Borobudur University, Jakarta, Indonesia ${ }^{1,2}$ \\ \{davied7321@gmail.com¹,cclsis@yahoo.com²\}
}

\begin{abstract}
People in Indonesia recognize two marriage laws, namely state law and customary law. The Dayak Kadorih tribe has a binding customary law of marriage and has its customary law consequences. In terms of positive law in the perspective of Law Number 1 of 1974 concerning Marriage, it is found that if there are problems in traditional marriages, the state cannot be present in protecting legal subjects who carry out customary marriages. Customary marriage problems can only be resolved through customary law within the local community.
\end{abstract}

Keywords: Marriage; Custom; Customary law; Dayak Kadorih

\section{Preliminary}

Indonesia is a country with a cosmopolitan character. The most dominant element in cosmopolitanism is an eclectic religious life, in which the Indonesian people can develop their philosophical thoughts by sorting from various sources that have been passed through for centuries. This character can be seen from the reality of the diversity of religions and beliefs that thrive as a result of pluralization. There are several religions and tens or even hundreds of sects of a belief that are still alive and thriving in society. [1]

The plurality possessed by the Indonesian nation shows that this tradition of tolerance has been built naturally in society before the advent of religion. Thus, recognition and tolerance are not only for different religions but also for different faiths. This is important to note as the historical experience of the Indonesian nation will influence the nation's mindset in the future. A nation cannot develop a new tradition that is separate from its historical roots.

Forms of the plurality include ethnicity, religion, race, and class. Within each ethnicity and religion, there is uniqueness related to the procedures for both regulating society and the customs that exist within it. The most significant thing is regarding the tradition of marriage. Each tribe has different traditions and cultures when it comes to marriage. Different traditions and procedures for traditional marriage make a unique and cultural richness for the Unitary State of the Republic of Indonesia. This cultural wealth needs to be cared for by providing a forum and rules for regulating marriage in society. One of the bases for the marriage law is Law No.1 of 1974.

Law No.1 / 1974 Article 2 (1) states that a marriage is legal if it is carried out according to the law of each religion and belief and (2) each marriage is recorded according to the 
applicable statutory regulations. Law No.23 / 2006 Article 34 (1) a legal marriage must be reported by residents to the implementing agency at the place where the marriage took place no later than 60 days from the date of marriage. Paragraph (4) The reporting for residents who are Muslim is carried out at the sub-district KUA, for non-Muslim citizens at the civil registry office. The stage of marriage (for adherents of both Muslim and non-Muslim religions) is that a husband-wife candidate registers themselves at the KUA or the Civil Registry Office who then carries out the marriage and is given a marriage certificate. After that, the KUA or others will inform the implementation of the marriage to the Civil Registry Office.

For adherents of belief, accommodated by PP No.37 / 2007 concerning the implementation of Law No.23 / 2006. In the Law in Article 1 (18) it is shown that belief in God Almighty (TYME) or believers of belief is a statement and implementation of a personal relationship with TYME based on a belief that is manifested by devout behavior and worship of TYME and the practice of virtue whose teachings come from Indonesian local wisdom. Whereas in paragraph (20), the marriage certificate of the believer's believer is made, signed, and legalized by the leader of the believer.

The Kadorih Dayak tribe who live in Central Kalimantan are still preserving their traditions, customs, and beliefs. In their activities and community life, the Kadorih Dayak tribe still holds to their traditions and beliefs in the teachings of their ancestors. Both in work, work management to marriage. Many members of the Kadorih Dayak tribe are married in customary ways without being legally married in government institutions, or their marriages are not registered in government institutions. In connection with these customary marriages, how do the marriage laws in Indonesia, especially in Law No.1 / 1974 address this? This paper will conduct an analysis related to the law of marriage as stipulated in Law No.1 / 1974 in the customary marriage of the Kadorih Dayak Tribe.

\section{Research Method}

This study uses a type of normative legal research, which is a type of research that focuses on the legal framework that is built into a statutory regulation. [2] By using a descriptiveanalytic rule of law related to existing research themes, then examined using data sources derived from literature and factual data in the field. The data that has been collected is then analyzed using analytical descriptive analysis techniques, namely by studying in-depth the existing regulatory review materials. [3] Through these analytical techniques, it is hoped that they will be able to find answers to the research questions that have been described in the previous section.

\section{Discussion}

According to the provisions of Article 1 of Law No.1 of 1974 concerning Marriage, marriage is a physical and spiritual bond between a man and a woman, as husband and wife by forming a happy and eternal family (household) based on Almighty God. Following the formulation of the definition of marriage, it can be seen that in a marriage there are 3 (three) main elements contained therein, namely as follows:

a. Marriage is a physical and spiritual bond between a man and a woman.

b. Marriage aims to form a happy and eternal family (household).

c. Marriage based on the Supreme Lordship. 
The description of the definition of marriage as referred to in Article 1 of Law No.1 of 1974 concerning Marriage, by Abdulkadir Muhammad is explained as follows :

a. A birth bond is a formal relationship that can be seen because it is formed according to law, which is a relationship that binds two parties and other parties in society. Meanwhile, the inner bond is an informal relationship that is formed by mutual willingness which binds only the two parties.

b. Between a man and a woman, meaning that in one period the inner and outer bond only occurs between man and woman. Men and women are genders as gifts of God, not human formation.

c. Husband and wife, are the functions of each party as a result of the existence of a physical and mental bond, meaning that there is no function as husband and wife.

d. Every marriage must have a purpose, where the purpose is summed up in the function of husband and wife, therefore there can be no function of husband and wife without containing a purpose.

e. Forming a family, which means forming the smallest community unit. consisting of husband, wife, and children. Forming a household means forming a union of husband and wife relationships in a container called a common residence.

f. Happy, which means there is harmony in the relationship between husband, wife, and children in the household.

g. Eternal, meaning that it is immediately continuous for life and should not be just decided or dissolved according to the will of the husband and wife.

h. Marriage is based on the Supreme Lordship, meaning that marriage does not just happen or is dissolved according to the wishes of the parties but as a gift from God to humans as civilized beings. That is the reason so that marriages are carried out in a civilized manner under religious teachings passed down to humans.[4]

Law No.1 / 1974 Article 2 has regulated the provisions of a legal marriage if it is carried out according to the law of each religion and belief. In his further explanation, it is written that every marriage that has been carried out based on the law of religion and belief needs to be registered according to the prevailing laws and regulations. Then an explanation is given, namely, the recording is carried out a maximum of 60 days after the marriage was carried out. For Muslims, the registration is done at the Office of Religious Affairs and for non-Muslims, it is done at the Civil Registry Office.[5]

To achieve a happy and eternal family by the purpose of marriage according to Law no. 1 of 1974 concerning Marriage, then that happiness must be felt by all family members, be it husband, wife, and children. This is because family happiness must be arranged based on the individual happiness of each family member that does not prioritize personal interests and happiness. Thus it is impossible to achieve a happy family if each family member is only concerned with individual happiness, as opposed to shared happiness in the family.

Unlike Muslims and non-Muslims, people who adhere to the belief system of marriage regulations are also emphasized in Government Regulation No. 37/2007 regarding its implementation as stated in Law No. 23/2006. It is stated that belief in God Almighty or believers of faith is a community that performs worship and piety in the context of practicing local wisdom from the ancestors of the Indonesian nation. In connection with the terms and marriage certificate, it was made and legalized by the leaders of his belief.[6]

According to customary law in general in Indonesia, marriage is not only an agreement, Adat but also kinship and neighborly agreement. It can be said that according to customary law, a marriage bond does not merely result in a civil relationship, such as the rights and obligations of husband and wife, joint property, the position of the child, the rights and 
obligations of parents, but also relates to inheritance customary relationships, kinship, kinship, and neighborliness as well as regarding traditional and religious ceremonies. So marriage is a matter of relatives, family affairs, community affairs, affairs of rank, and personal affairs, with each other in very different relationships. [7] But even though it is a family affair, a family affair, and a fellowship affair, marriage remains a matter of private life of the individual parties who happen to be involved in it.

As in Circular No.01 / SE / NBSF / VIII / '07 dated 1/8/2007 by the General Director of Cultural Values, Arts and Film, Ministry of Culture and Tourism concerning the Appointment and Appointment of Beliefs' Leaders, it is also stated: in connection with the promulgation of Law 23/2006 concerning Population Administration and PP No.37 / 2007 Chapter X, the requirements and procedures for recording marriages for believers of article 81 are as follows: [8]

a. Marriage with a believer in a belief is conducted in the presence of a leader of the believer's religion;

b. Trustees as referred to in paragraph (1) shall be appointed and stipulated by the organization of believers to fill in and sign the marriage certificate for the believers of trust;

c. Belief leaders as referred to in paragraph (2) are registered with the ministry whose field of duty is technically fostering organizations of belief in The One Almighty God, in the form of:

1. So that based on members' deliberations, they can immediately appoint and assign a leader of the believers of faith in the organization of the believers who are tasked with filling out and signing the Marriage Certificate of the Believers to The One Almighty God,

2. The number of religious leaders appointed and stipulated by the organization of the followers of the trust submits according to the needs/sufficiency of the branch area and distribution of the organization.

3. Belief leaders who have been appointed and assigned to immediately register with the Directorate of Belief in God Almighty to obtain the Decree of the Director of Belief in God Almighty regarding the determination of their authority.

4. Belief leaders who have been registered with the Directorate of Belief in God Almighty must be completed with their residential address and two 4x6 color photographs.

Tjilik Riwut in his book Kalimantan Builds Nature and Culture, the Kalimantan Dayak tribe consists of 7 tribes, and the seven tribes consist of 18 tribal children who are sedatuk, and 18 tribes who are not sedatuk who are sedatuk consisting of 405 family tribes. [9] In the past, the people who are now called the Dayak tribe inhabited the coastal areas and rivers in each of their settlements and inland. The strong currents of urbanization that have influenced from outside, such as Malay, have caused them to flee further into the interior and hills throughout Kalimantan.

On average, Dayak tribes who still maintain their traditions and customs live far from the city center. They used to live in forests and along rivers that cut through Kalimantan and away from the crowds. Likewise, the Kadorih Dayak tribe lives in the upper reaches of the Barito River, which is far from the crowd. Settlements that are far from the crowd and the city center are what cause the level of education that is passed and owned is also very minimal. The limited educational infrastructure is one of the obstacles in enjoying a higher level of education. If they want to enter a higher level of education, they have to go to a sub-district 
city that is far from their place of residence, so it requires a lot of money and time because only elementary school education is in the area where they live.

This low level of education is also one of the reasons why the level of legal awareness of the community is far from what is expected, as a law order society. Law No.1 of 1974 concerning Marriage and its Implementing Regulations do not provide strict sanctions in this case criminal sanctions which have a deterrent effect on society, especially for people who are not civil servants. A statutory regulation that carries the threat of strict sanctions is very effective to be obeyed by every individual in society, this is actually must be owned by Law No.1 of 1974 concerning Marriage, especially the regulation of the legalization and registration of marriage.

Ratification and registration are one of the conditions for marriage according to Law No.1 of 1974 concerning Marriage. In the community of the Kadorih Dayak Tribe, in reality, there are still many marriages that are carried out based on Customary Law and only get approval from religious institutions without being followed by registration by the civil registration institution, so the requirements according to Law no. 1 of 1974 concerning Marriage there are still things that have not been implemented properly following the expectations of the Law.

With the enactment of Law No.1 of 1974 concerning Marriage, among the Dayak Kadorih Tribe the implementation of marriage is carried out in 2 (two) forms, namely marriage which is carried out according to Law No.1 of 1974 concerning Marriage and the marriage which is carried out is a mixture of customary rules and regulations. Ecclesiastical, namely marriages whose processions are based on customary law and are legalized by the Church, in this case, the Pastors, because the Kadorih Dayak people adhere to Protestant Christianity of approximately $90 \%$ (ninety percent). [10]

The Dayak Kadorih people who carry out marriages based on a mixture of customary rules and church rules are still quite numerous, this is since the Dayak Kadorih people adhere to customary laws and their religious laws. According to the view of the Dayak Kadorih tribe, customary law is a law that lives and is maintained in the community's association and has a very large effect on the legal system prevailing in the community, and its implementation must not conflict with the religious rules they adhere to.

Based on existing studies, it appears that the Kadorih Dayak people try to adjust to the state law related to marriage. This adjustment is due to the requirements of the school when their child or offspring wants to continue their studies in formal schools. This requirement that requires a birth certificate and a birth certificate in the form of a state marriage certificate then "forces" the Kadorih Dayak people to carry out administrative requirements related to their marriage to the state. Traditional marriages that have not been fully recognized by the state make them adapt and adapt to the existing government provisions.

\section{Conclusion}

In the implementation of marriage according to Law No.1 of 1974 concerning Marriage, it turns out that the Kadorih Dayak people, in reality, have not yet fully performed them, because many marriages are carried out according to customary law. The Dayak Kadorih tribe considers that marriage according to customary law must be fulfilled and completed, and there is no strict sanction if a member of the community does not marry under the provisions of Article 2 of Law No.1 of 1974 concerning Marriage. This is because the customary law community is stronger in the life order of the Kadorih Dayak tribe so that when problems occur in their marriage, only customary law can solve them. 


\section{References}

[1] Z. Zakiyah, "EDUCATION TO BELIEVE IN GOD ALMIGHTY: FULFILLING THE RIGHTS OF SCHOOL STUDENTS," Penamas, vol. 31, no. 2, p. 397, Dec. 2018, doi: 10.31330 / penamas.v31i2.232.

[2] J. Ibrahim, "Theory and Research Methods of Normative Law," Bayu Media, Malang, 2006.

[3] S. Irianto, "QUALITATIVE RESEARCH METHODS IN LEGAL SCIENCE RESEARCH METHODOLOGY," J. Huk. Pembang., Vol. 32, no. 2, p. 155, Jun. 2017 , doi: 10.21143 / jhp.vol32.no2.1339.

[4] A. Muhammad, Indonesian Civil Law. Bandung: PT. Citra Aditya Bakti, 1990.

[5] Sukirno, "Discrimination of Fulfillment of Civil Rights for Adherents of Local Religions," Adm. Law Gov. J., vol. 1, no. 3, pp. 231-239, 2018, [Online]. Available: https://ejournal2.undip.ac.id/index.php/alj/article/view/3804/2123.

[6] M. Dahlan and A. Liemanto, "Legal Protection of the Constitutional Rights of Adherents of Local Religions in Indonesia," Arena Huk., Vol. 10, no. 1, pp. 20-39, 2017, doi: 10.21776 / ub. Because of the law. 2017.01001.2.

[7] T. Haar, Principles and Composition of Customary Law (Begensilen en Stelsel Yan Het Adatrecht), Translation K. Ng. Soebakti Poespo Noto. Jakarta: Pradnya Paramita, 1960.

[8] M. A. Primadhani, "The Legality of Marriage Conducted by Indigenous Peoples of the Inner Tribal Children after the enactment of Law Number 1 of 1974 Concerning," Legalitatum, vol. 1, no. 1, pp. 11-27, 2019.

[9] T. Riwut, Kalimantan Developing Nature and Culture. Solo: NR Publishing, 2007.

[10] Fillipus, "Interview with the Traditional Head of the Kadorih Dayak Tribe," Source Barito. 